\title{
Михнева Светлана Владимировна
}

канд. юрид. наук, доцент Российская академия наук (РАН), доцент Бузаева Саида Шамилевна студентка

Волгоградский институт управления (филиал) ФГБОУ ВО «Российская академия народного хозяйства и государственной службы при Президенте РФ» г. Волгоград, Волгоградская область

DOI $10.21661 / r-470292$

\section{ИСТОЧНИКИ СОВРЕМЕННОГО РОССИЙСКОГО ПРАВА}

Аннотация: в данной статье рассмотрена проблема источников права современной России. Охарактеризован нормативно-правовой акт как основной источник права, выделены виды нормативно-правовых актов. Обозначено значение правового прецедента.

Ключевые слова: источник права, форма права, закон, нормативно-правовой акт, подзаконные акты, муниципальные правовые акты, судебный прецедент.

В юридической науке наряду с научно выработанными и нормативно закрепленными категориями существуют термины и понятия, имеющие неоднозначную трактовку и различное смысловое содержание. К их числу относятся понятия «источник» или «форма» права, трактовка которых носит дискуссионный характер, в связи с чем, в науке и в юридической практике не достигнуто единства точек зрения относительно понимания источника права.

Относительно соотношения понятий «форма права» и «источник права» сложилось несколько точек зрения. Одни авторы считают, что источник права и форма права - это обособленные самостоятельные понятия, обладающие собственным содержанием, аргументируя это тем, что форма права указывает на способы официального закрепления и внешнего существования юридических 
норм, а источники права - это истоки и факторы социального характера, обуславливающие существование права и его внутреннее содержание [1; 3-4]. Сторонники противоположной точки зрения исходят из тождественности указанных категорий [2]. Источники права, по их мнению, есть способ выражения государственной воли - то есть форма права. Доминирующей в настоящее время является третья позиция, опирающаяся на компромиссный характер, согласно которой источники и формы права рассматриваются в качестве понятий, совпадающих лишь частично в формально юридическом смысле. На наш взгляд, дискуссионность трактовки понятий объясняет наличие различий в правопонимании. В связи с чем, предлагается под источниками права понимать исходные принципы и нормы правового регулирования, а под формами - способы их официального закрепления, информационные, документальные, фактические носители, содержащие эти нормы [5; 6-7].

Источники права характеризуются как категория более широкая по смыслу, в связи с чем, различают источники права в историческом, материальном, идеальном, формально-юридическом и других значениях. Таким образом, формы (источники) права - это внешние официально-документальные формы выражения и закрепления норм права, исходящие от государства. Несмотря на разнообразие и значительную специфику действующих источников права, всем им присущи некоторые общие черты. Источник права есть конечный итог правотворческой деятельности определенных субъектов, управомоченных формировать право, так своеобразие действующих в обществе источников права обусловлено спецификой их происхождения. Источник права имеет нормативный и официальный характер. Источник права нацелен на стабильность, предсказуемость. Он фиксируется в определенных письменных формах, поэтому обеспечивается их доступность, общеизвестность, единообразное понимание и применение на практике. Важнейшим свойством источников права является их иерархичность, благодаря чему они и внешне выражают, и организуют, структурируют государственную волю. 
В настоящее время юриспруденция и практика правового регулирования выделяют несколько видов источников права. Наиболее распространенными являются: правовой обычай, правовой прецедент, нормативный договор, правовая доктрина, нормативно-правовой акт. Названные источники права обладают целым рядом особенностей. Одни из них устанавливаются в результате целенаправленной деятельности специальных государственных органов, например, нормативно-правовой акт, другие вырабатываются общественной жизнью на протяжении определенного исторического развития и в последующем лишь одобряются и санкционируются государством, в частности, правовой обычай, третьи создаются в процессе разрешения компетентными органами конкретных жизненных споров, ситуаций - правовой прецедент. Обратимся к наиболее типичным и важным источникам права.

Одним из древнейших источников права является правовой обычай, представляющий собой нормы, которые сложились в обществе в результате многократного применения независимо от государственной власти и приобрели в его сознании обязательное значение. Обычай становится правовым после получения одобрения государства и закрепления его как юридического источника. В результате государственно-властное санкционирование придает обязательность норме социального обычая, который в своей реализации обеспечивается мерами государственного принуждения. Обычно-правовое регулирование играло особенно большую роль в период зарождения, становления и развития государства. Правотворческая деятельность государства тогда осуществлялась в основном в виде принятия и одобрения сложившихся обычаев. С развитием государственности правовой обычай утрачивал ведущие позиции в системе источников права, уступая актам государства. Современная роль правовых обычаев в регулировании общественных отношений обусловлена признанием его одним из официальных источников права в российской правовой системе. Возможность его использования предусмотрена в частноправовой сфере: в гражданской и семейной отраслях. Так, статья 5 ГК РФ, посвященная обычаям, закрепляет, что обычаем признается сложившееся и широко применяемое в какой-либо области 
правоприменительной деятельности правило поведения, не предусмотренное законодательством, независимо от того, зафиксировано оно в каком-либо документе. Так же Кодекс торгового мореплавания РФ от 30.04.1999 г. в статье 129 «Уведомление о готовности судна к погрузке груза» в пункте втором закрепляет, что день и час подачи уведомления о готовности судна к погрузке определяется соглашением сторон, а при отсутствии такового - обычаями данного порта. Также следует отметить тот факт, что в Конституции РФ 1993 года не упоминается понятие «обычай», но в статье 99 пункте 3 закреплено: «Первое заседание Государственной думы открывает старейший по возрасту депутат», то есть, таким образом, действует формальный обычай, который существует на протяжении многих лет [2-4; 7].

В России важнейшим и основным источником права является закон, который представляет собой нормативно-правовой акт, обладающий высшей юридической силой и регулирующий важнейшие вопросы внутригосударственной жизни, принятый в особом процессуальном порядке законотворческим органом. Закон обладает такими признаками, как: принятие специально уполномоченным законодательным органом государственной власти; направлен на регулирование значимых общественных отношений; особый процессуальный порядок принятия; обладание высшей юридической силой; общеобязательность.

Возрастание роли правового прецедента также требует незамедлительного анализа места и роли его в системе источников права, а, следовательно, и в современной российской правовой системе общества, учитывая особенности судебной системы РФ, ее принципы в правовом государстве. Анализ понятия, сущности и назначения правового прецедента в РФ демонстрирует неоднозначное отношение к нему как ученых, так и правоприменителей в связи с его значением как источника (формы) права. Однако, официально судебный прецедент не признается источником современного российского права, несмотря на его возрастающее значение как источника права в правовой российской системе.

Неоспорим и тот факт, что социально-экономические, политические, информационные и иные условия общественной жизни нашего государства, 
динамично развиваясь, закономерно увеличивают неурегулированные стороны правовой действительности, законодательные пробелы. В этом случае, в целях эффективного своевременного правового регулирования социальных отношений неизбежно обращение к правовой научной доктрине, которая формирует фундамент юридической науки, систематически и последовательно развивая ее и дополняя.

Таким образом, в настоящее время в Российской правовой системе выделяются следующие источники или формы права: правовой обычай, нормативноправовой акт, важной разновидностью которого является закон, научная доктрина. Правовой обычай продолжает оставаться одним из источников современного права. Вместе с тем его использование ограничено достаточно узкими сферами общественных отношений и, в целом, он имеет значение дополнительного источника.

Подводя итог и обобщая результаты анализа теоретических научных изысканий по формулированию определений и трактовок источников права, можно отметить, что в юридической науке наиболее распространено их понимание как формы установления и выражения (существования) действующих правовых норм или специфической (особой) формы изъявления воли и придания ей значения общеобязательной нормы.

\section{Сиисок литературы}

1. Еременко Ю.П. Предмет российского конституционного права. - Ростов н/Д: РВШ МВД России. - 1996. - 50 с.

2. Михнева С.В. Профессиональное благополучие государственных служащих как социальной группы // Психология и педагогика XXI века: теория, практика и перспективы: Материалы V Междунар. науч.-практ. конф. (Чебоксары, 28 мая 2017 г.) / Редкол.: О.Н. Широков [и др.] - Чебоксары: ЦНС «Интерактив плюс», 2017. - С. 246-248.

3. Сорокина Н.В. Правовое регулирование и кадровая обеспеченность органов местного самоуправления: исторический аспект и современные основы 
(учебное пособие) / Н.В. Сорокина, С.В. Михнева. - Волгоград: Волгоградское научное издательство, 2013. - 211 с.

4. Михнева С.В. Правовой статус муниципального служащего в России (Нижневолжский регион): Автореферат дис... канд. юр. Наук. - Волгоград: Волгогр. акад. МВД России, 2003. - 30 с.

5. Митячкина Е.С. Правовое регулирование положения главы местной администрации и муниципального служащего в Российской Федерации / Е.С. Митячкина, С.В. Михнева // Гуманитарные исследования. - 2016. - №2 (58). - C. 157-162.

6. Михнева С.В. Ценностные характеристики местного самоуправления. / C.В. Михнева, Е.С. Митячкина // Гуманитарные исследования. - 2017. - №4 (64). - C. 248-253.

7. Матузов Н.И. Теория государства и права: Учебник / Н.И. Матузов, А.В. Малько. - М., 2002. 